Research Article

\title{
Theoretical and Experimental Studies of Two-Span Reinforced Concrete Deep Beams and Comparisons with Strut-and-Tie Method
}

\author{
Mahsa Zargarian (iD) and Alireza Rahai \\ Department of Civil Engineering, Amir Kabir University, Tehran, Iran \\ Correspondence should be addressed to Alireza Rahai; rahai@aut.ac.ir
}

Received 13 April 2020; Revised 18 January 2021; Accepted 25 January 2021; Published 8 February 2021

Academic Editor: Marco Corradi

Copyright ( 2021 Mahsa Zargarian and Alireza Rahai. This is an open access article distributed under the Creative Commons Attribution License, which permits unrestricted use, distribution, and reproduction in any medium, provided the original work is properly cited.

\begin{abstract}
Regarding the complicated behavior of continuous deep beams, a research program including three parts was conducted. First part: three continuous concrete deep beams with different shear span-to-depth ratios $(a / h)$ were tested. The effects of varying $a / h$ ratio on ultimate strength and failure modes were investigated. Second part: the nonlinear finite element (FE) analyses were performed to simulate the experimental specimens and 21 large-scale continuous deep beams. The main parameters investigated were $a / h$ ratio from 0.33 to 2 and $f_{c}^{\prime}$ considered $40 \mathrm{MPa}, 60 \mathrm{MPa}$, and $80 \mathrm{MPa}$. Third part: the strut-and-tie modeling of different design codes and indeterminate strut-tie method were studied for continuous deep beams. Regardless of the $a / h$ ratio, all beam specimens failed in shear mode with main diagonal cracks. Although EC2 load prediction was conservative for all beam models, the ACI and CSA predictions for concrete deep beams with high compressive strength were unsafe. The indeterminate truss model showed closer results to FE analysis in comparison with ACI, EC2, and CSA strut-and-tie method.
\end{abstract}

\section{Introduction}

Deep beams are used in shear walls, transfer girders, silos, dams, bridges, and tall buildings. The shear behavior of a simply supported reinforced concrete (RC) beam is complex because of the large number of parameters involved [1]. It becomes even more sophisticated for continuous RC deep beams due to their small shear span-to-depth ratio and statically indeterminate nature.

In deep beams, the structural response is determined by the nonlinear strain distribution even in the elastic area, in contrast to ordinary beams. Besides, since shear deformation is not negligible, ordinary beam theory cannot predict the deep beams' load distribution. Furthermore, in the continuous concrete deep beams, maximum negative moment and maximum shear occurred at the same point. The contra flexure's points in continuous beams might have occurred next to the critical sections of shear. Therefore, the experimental load capacity equations prepared for simply supported RC deep beams are not suitable for continuous deep beams [2].

The deep beam is specified as having a clear span $(l)$ equal to or less than four times the overall depth $(h)$ or a beam in which its concentrated loads are within a space of $2 \mathrm{~h}$ from the face of the support, by "The American Building Code" [3]. Alternatively, a deep beam is defined as having $1 / h$ ratio less than 3 by "The Euro Code 2" (EC2) [4], when "The Canadian Code" [5] defines a deep beam with $1 / h$ ratio less than 2.

To analyze deep beams, it is commonly recommended to use "strut-and-tie modeling." This model is created on the basic characteristic of direct transfer of shear forces from the load points to the supports through compression stresses (arch action) [3, 5-7]. An indeterminate and determinate strut-tie modeling has been mentioned by FIB (2010) for simply supported deep beams. This model recommends an arch load transfer mechanism for beams with $a / z \leq 0.5$ ( $a$ is the shear span and $z$ is the distance between the top and 
bottom longitudinal reinforcement). The model suggests the truss load transfer mechanism for beams with $a / z \geq 2$. It also proposed a mixture of an arch and truss load transfer mechanisms as an indeterminate strut-tie model for beams with $0.5<a / z<2[8]$.

Several research types have been done on single-span deep beams; however, the deep beams used in engineering structures are mostly continuous ones [9-15].

Chen et al. [16] revealed that the stress distribution and crack patterns of continuous deep beams and simple deep beams are different. The continuous deep beam's diagonal strut had a higher degree of deterioration than a simple deep beam with the same parameters and characteristics.

Oh and Shin's study [14] revealed that deep beams with low $a / d$ ratio ( $a$ is the shear span and $d$ is effective depth) and high strength concrete suddenly failed without any prognosis. Regardless of concrete compressive strength, deep beams' final failure modes depend on the a/d ratio. Singh et al. [2] showed that continuous deep beams follow the general trend of increased shear strength with a decrease in $a / h$ ratio, similar to simply supported deep beams. Yang et al. [17] indicated that beams with a low $a / h$ ratio had failed with main diagonal cracks, and $a / h$ ratio has a major effect on the growth of diagonal cracks. They also revealed that the effect of section depth $(h)$ on ultimate strength is more noticeable in continuous deep beams and high strength concrete beams than simply supported beams.

Ashour and Morley's study [18] showed that web reinforcement of continuous deep beams is related to the $a / h$ ratio, and the ultimate loads of continuous deep beams are influenced by the web reinforcement. Thus, it is concluded that the final load capacity of continuous deep beams is dependent on the $a / h$ ratio. Yang and Ashour [19] reported that, with increasing concrete compressive strength, the ultimate load capacity of concrete continuous beams would be increased. It is also mentioned that, with an increasing $a / h$ ratio, the load capacity will be decreased.

Arabzadeh's study [20] showed that the bottom reinforcements in continuous deep beams have an important influence on failure modes and ultimate load-bearing capacity. He also revealed that the midspan deflection is the maximum deflection in deep beams regardless of boundary conditions.

Aguilar et al. [9] reported that ACI building code, either in shear design or in strut-and-tie design, has a conservative estimate of single-span beams' shear strength. Khatab et al. [21] revealed that the ultimate capacity of continuous deep beams with low and medium strength concrete has a good agreement with strut-and-tie predictions of different design codes.

Chen et al. [22] proposed a cracking strut-and-tie model for continuous deep beams. This model considers the effect of web-shear crack on the STM of these beams. They showed that the cracking strut-and-tie model correctly predicts the effect of $a / h$ ratio, reinforcement ratio, effective depth, and concrete compressive strength on these beams' shear strength.

In this research, an experimental study of continuous deep beams was investigated along with the tested specimens' numerical study. The FE analysis results and earlier experimental data were compared. Also, the numerical study of 21 full-scale continuous deep beams was conducted. The results were evaluated with strut-and-tie modeling of three different design codes and the indeterminate strut-tie method.

\section{Experimental Study}

2.1. Test Specimens. In this research, three continuous reinforced concrete deep beams were prepared and tested. The overall geometric dimensions and details of reinforcement for specimens are revealed in Tables 1 and 2 and Figure 1. All specimens had the same overall length, clear span, and width equal to $L=1500 \mathrm{~mm}, l=500 \mathrm{~mm}$, and $b=100 \mathrm{~mm}$, respectively. The main parameter to be studied was the shear spanto-overall depth ratio $(a / h)$. To develop three different $a / h$ ratios, the overall depth $(h)$ was considered $h=250 \mathrm{~mm}$ for BT1, $h=500 \mathrm{~mm}$ for BT2, and $h=750 \mathrm{~mm}$ for BT3. According to Librescu and Song [23], the beam can be categorized as a slender, thin beam when $b / h \leq 0.1$ and $h / l \leq 0.1$; otherwise, it is a thick beam. The experimental specimens were thick beams and did not need to be maintained from the out-of-plane stability.

Details of reinforcement for specimens are shown in Figure 1. Additional reinforcement cages were provided at each loading and reaction points to prevent premature local failure. The material properties of concrete and steel are presented in Tables 1 and 2 .

2.2. Test Setup. A $3000 \mathrm{kN}$ capacity testing frame was used to test the specimens under five-point loading, shown in Figure 2. Some steel plates were positioned between the loading points and the deep beams to avoid local failure in loading points. The lengths of steel plates were defined based on the ACI strut-and-tie model. The bearing stresses applied by the steel plates on the underlying nodes should be less than the allowable bearing stresses for these nodes. Side support plates and loading plates were considered with an equal length of $150 \mathrm{~mm}$. To prevent the concrete crushing at the middle support zone, the plate had a length of $200 \mathrm{~mm}$. In other words, due to the bigger dimensions of the steel plate at the middle support, the crushing of concrete does not happen at an early stage. A steel beam on top was used to divide the load into two loading points, as displayed in Figure 2. For measuring vertical deflection at midspans, two linear variable differential transformers (LVDTs) were mounted. A data logger was used to obtain the test results from LVDTs automatically.

\subsection{Experimental Results}

2.3.1. Cracking Behavior and Failure Modes. In beam specimen BT1, the first crack was shaped diagonal in the left span from loading plate to side support plate under $120 \mathrm{kN}$ of loading. By increasing the applied load, diagonal cracks were formed at both spans between the side support plate and loading plate. Due to proper bending reinforcement at 
TABLE 1: Geometrical and reinforcement features of the specimens.

\begin{tabular}{|c|c|c|c|c|c|c|c|c|c|c|}
\hline \multirow[t]{2}{*}{ Beam name } & \multirow[t]{2}{*}{$f_{c}^{\prime}(\mathrm{MPa})$} & \multirow[t]{2}{*}{$f_{t}^{\prime}(\mathrm{MPa})$} & \multirow[t]{2}{*}{$E(\mathrm{MPa})$} & \multirow[t]{2}{*}{$a(\mathrm{~mm})$} & \multirow[t]{2}{*}{$h(\mathrm{~mm})$} & \multirow[t]{2}{*}{$a / h$} & \multicolumn{2}{|c|}{$\begin{array}{l}\text { Longitudinal } \\
\text { reinforcement } \\
\text { ratio }\end{array}$} & \multicolumn{2}{|c|}{$\begin{array}{l}\text { Web reinforcement } \\
\text { ratio }\end{array}$} \\
\hline & & & & & & & Bottom & Top & Vertical & Horizontal \\
\hline$\overline{\mathrm{BT} 1}$ & 35 & 1.9 & 27800 & 250 & 250 & 1 & 0.018 & 0.018 & 0.0056 & 0.0056 \\
\hline BT2 & 40 & 2.1 & 29700 & 250 & 500 & 0.5 & 0.013 & 0.013 & 0.0056 & 0.0056 \\
\hline BT3 & 38 & 2 & 28900 & 250 & 750 & 0.33 & 0.009 & 0.009 & 0.0056 & 0.0056 \\
\hline
\end{tabular}

TABLE 2: Specifications of steel reinforcement.

\begin{tabular}{lccc}
\hline Bar diameter $(\mathrm{mm})$ & Yield strength $(\mathrm{MPa})$ & Ultimate strength $(\mathrm{MPa})$ & Elastic modulus $(\mathrm{MPa})$ \\
\hline 6 & 233 & 290 & 191320 \\
16 & 274 & 438 & 199540 \\
20 & 470 & 744 & 205000 \\
\hline
\end{tabular}
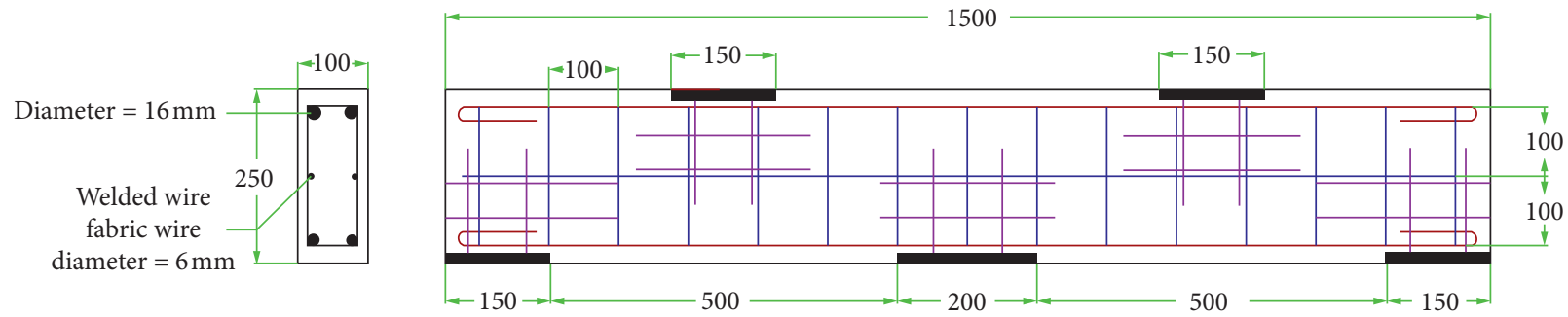

(a)
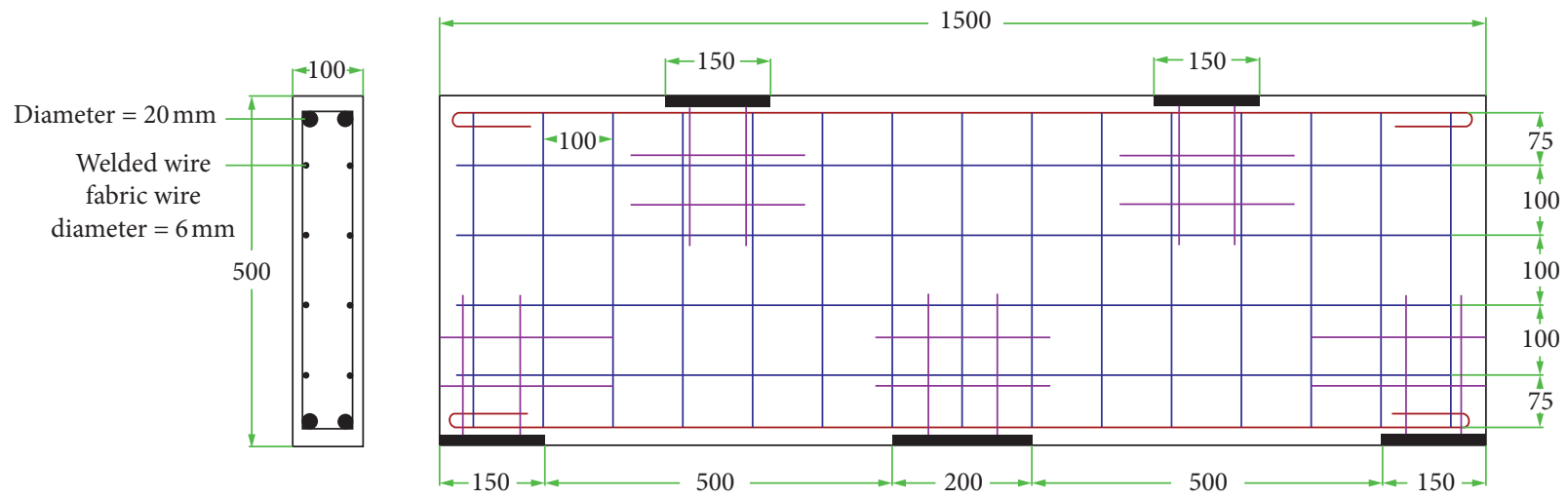

(b)

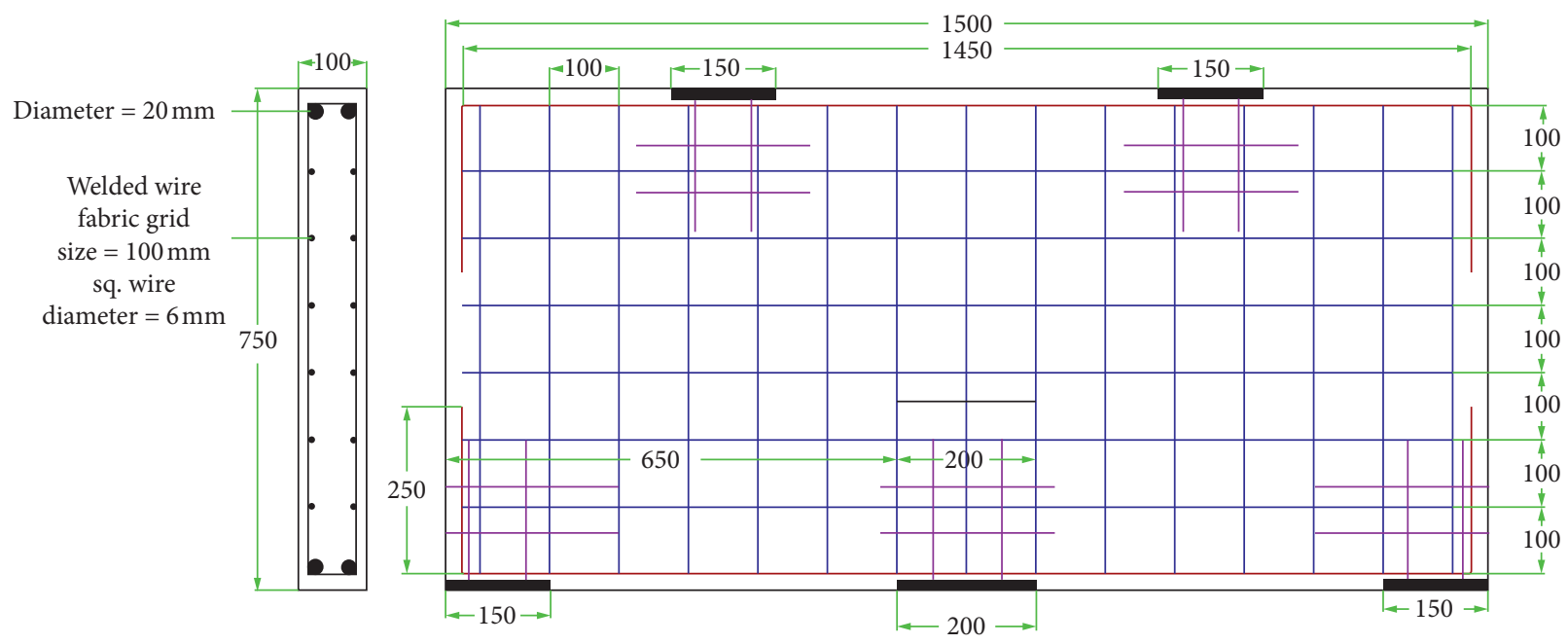

(c)

FIgURE 1: Details of reinforcing bars in beams. (a) BT1. (b) BT2. (c) BT3. 


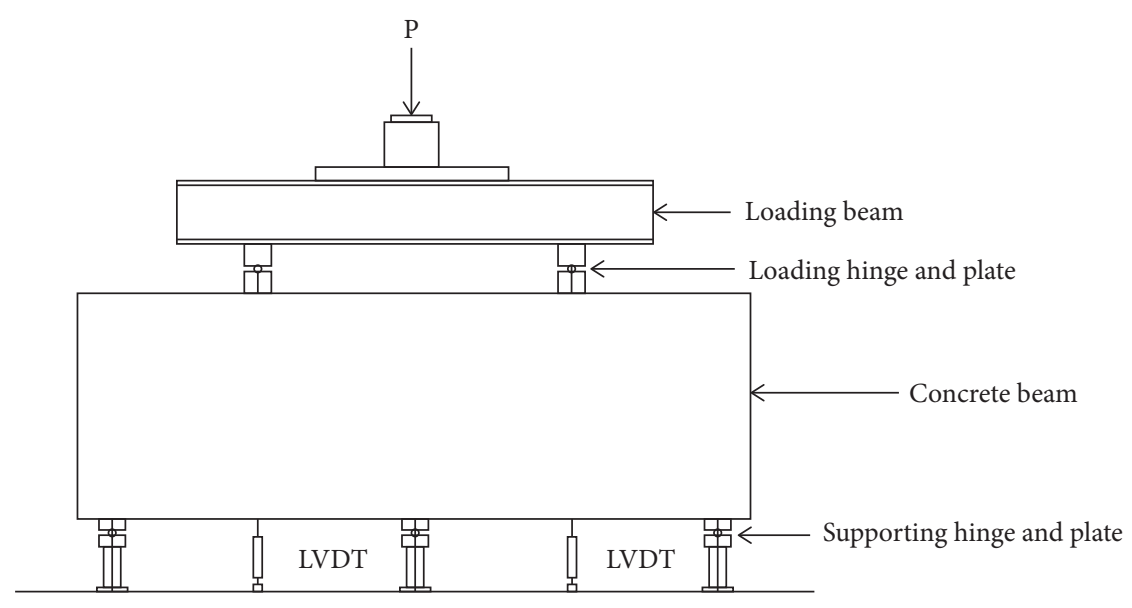

Figure 2: Test setup.

the top and bottom of the beam, no significant bending cracks were observed. Afterward, with the gradual increase in applied load, shear cracks appeared between the loading plate and the middle support. Finally, the beam failed at the load of $364 \mathrm{kN}$ with a midspan deflection of $9 \mathrm{~mm}$ in the shear mode, as shown in Figure 3. In beam specimen BT2, the first diagonal crack was gradually formed from the side support toward the beam's inner part under $351 \mathrm{kN}$ of loading. Then, some fine cracks were shaped parallel to the initial diagonal crack. At the load of $530 \mathrm{kN}$, cracks were created around the loading and side support plates. As increasing the applied load, shear cracks appeared between the loading and the middle support plate. Finally, the beam failed at the load of $760 \mathrm{kN}$ with a midspan deflection of $7.2 \mathrm{~mm}$ with brittle shear failure, as illustrated in Figure 3. The main failure modes in both BT1 and BT2 specimens were shear failure regardless of $(a / h)$ ratio, same as failure modes presented in past studies for continuous concrete deep beam $[17,24]$. In beam specimen BT3, the first crack was created near the side support plate at the load of $470 \mathrm{kN}$. By increasing the load to $670 \mathrm{kN}$, diagonal shear cracks were formed between the side support plates and loading plates. With increasing the applied load, local cracks were created under the loading plates. Then, the bending cracks, caused by negative moment, were formed at the top of the beam. Afterward, the BT3 specimen failed at a load of $1070 \mathrm{kN}$ and midspan deflection of $6.5 \mathrm{~mm}$ with major diagonal cracks along with concrete crushing and cracks nearby loading and support plates. The local support failure shows that the additional reinforcement provided near the loading and bearing plates was not enough to prevent premature failure. The cracked form of specimen BT3 is illustrated in Figure 3. Therefore, the failure mode was shear cracking and support failure. As it is shown in Table 3, the initial diagonal cracks were found at $32 \%, 46 \%$, and $43 \%$ of ultimate strength in specimens BT1, BT2, and BT3, respectively.

2.3.2. Load-Deflection Curves. Figure 4 displays the deflections at left midspan points of specimens with different $a / h$ ratios. As the left and right midspan deflections were so close to each other, all of the deflections illustrated in curves are related to the left midspan. As the $a / h$ ratio decreases, the initial stiffness and final load capacity increase, and the midspan deflection decreases. As the $a / h$ ratio increases and the beam height decreases, the beam behavior approaches the normal beam flexural behavior with high ductility. Therefore, by decreasing the $a / h$ ratio and increasing height, the structural function approaches the shear behavior, and the beams' ductility decreases. As shown in Figure 4, the BT3 specimen with $a / h=0.33$ is the stiffest specimen, and the BT1 specimen with $a / h=1$ has the most ductility. Like Rogowsky et al. and Ashour's research, the ductility of beams depends on the $a / h$ ratio $[24,25]$.

\section{Finite Element Analyses}

3.1. Modeling Assumptions. In this study, several models of the continuous concrete deep beams were analyzed using ABAQUS software [26].

Three-dimensional 8-noded brick first-order fully integration continuum elements (C3D8-Bricks) were adopted to model the continuous concrete deep beams and bearing and loading plates. The longitudinal reinforcing bars and the steel stirrups were discretized with three-dimensional 2node first-order linear truss elements (T3D2). To define the interaction of steel and concrete, all longitudinal and shear reinforcements were embedded in the concrete region.

The tie constraint is used to constrain each of the nodes on the bearing and loading plates to have the same value of displacement with the point on the concrete that it contacts. There is no relative displacement between two different surfaces, which are tied together by a tie constraint.

The mesh size is optimized to satisfy both computational time and accuracy. At the point of applying the load, to utilize an acceptable amplitude curve, the load was applied gradually as displacement offered on a steel plate. The FE model of continuous deep beams and the typical mesh is presented in Figure 5. For all beams, the same methods of modeling and mesh generation are applied.

The outline of either damage or plasticity or even both can be used to model the concrete nonlinearity [27]. Plasticity is characterized by the formation of unrecoverable 


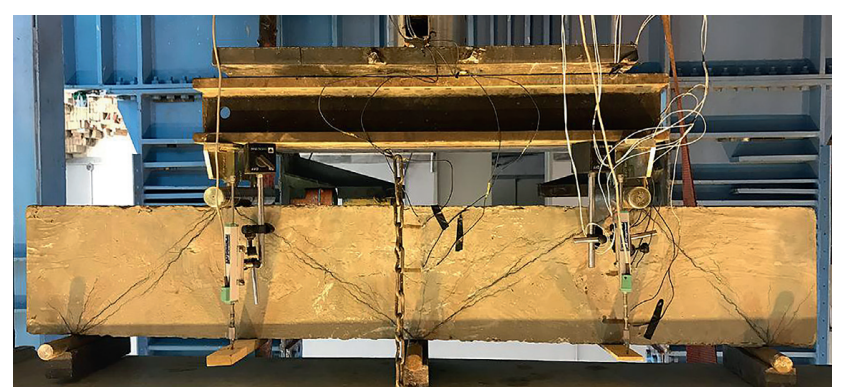

(a)

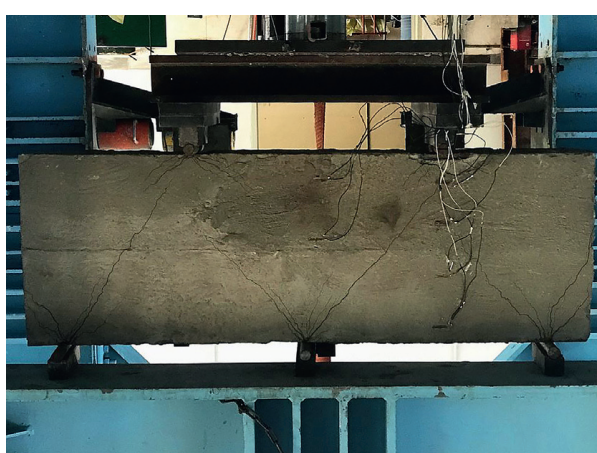

(b)

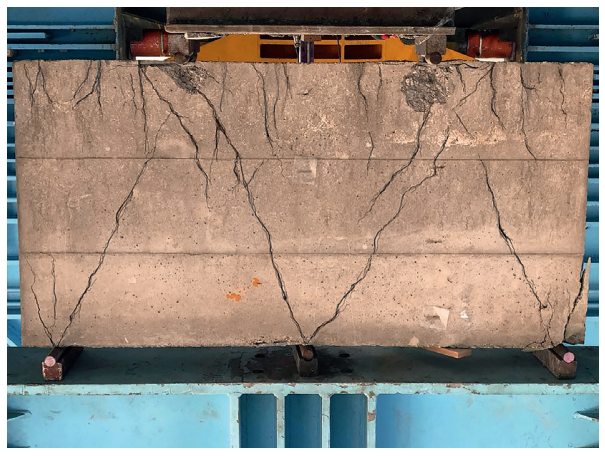

(c)

FIGURE 3: The cracked form of specimens. (a) BT1. (b) BT2. (c) BT3.

TABLE 3: Specifications of experimental specimens.

\begin{tabular}{lccccc}
\hline Beam name & $f_{c}^{\prime}(\mathrm{MPa})$ & $a / h$ & First crack load $(\mathrm{kN})$ & Experimental ultimate shear capacity $V_{\max }(\mathrm{kN})$ & Failure mode \\
\hline BT1 & 35 & 1 & 120 & 364 & Shear crack \\
BT2 & 40 & 0.5 & 351 & 760 & Shear crack \\
BT3 & 38 & 0.33 & 470 & 1070 & Shear crack + support failure \\
\hline
\end{tabular}

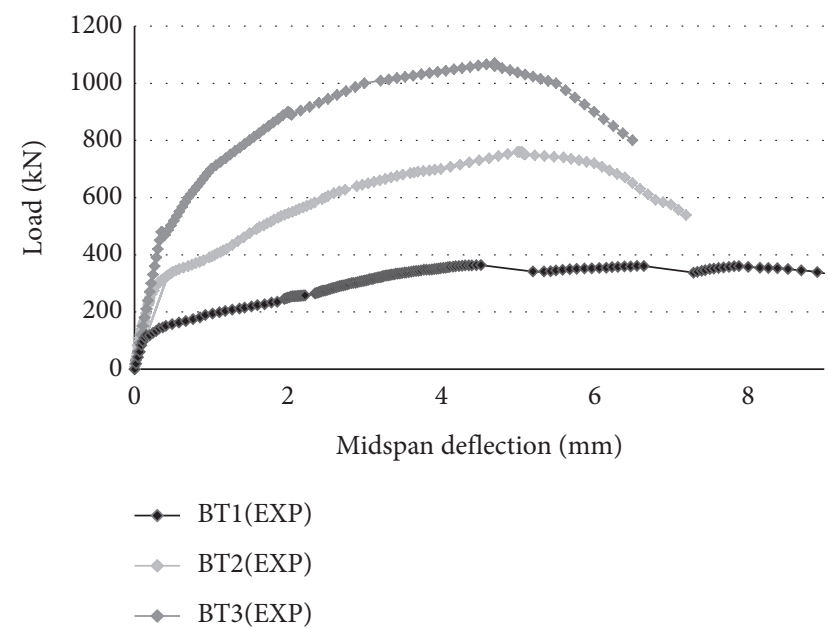

FIgURE 4: Load-deflection curves of test specimens.

deformation when loads are removed, and the lessening of elastic stiffness characterizes the damage. Since the concrete damage plasticity (CDP) model has been shown to work

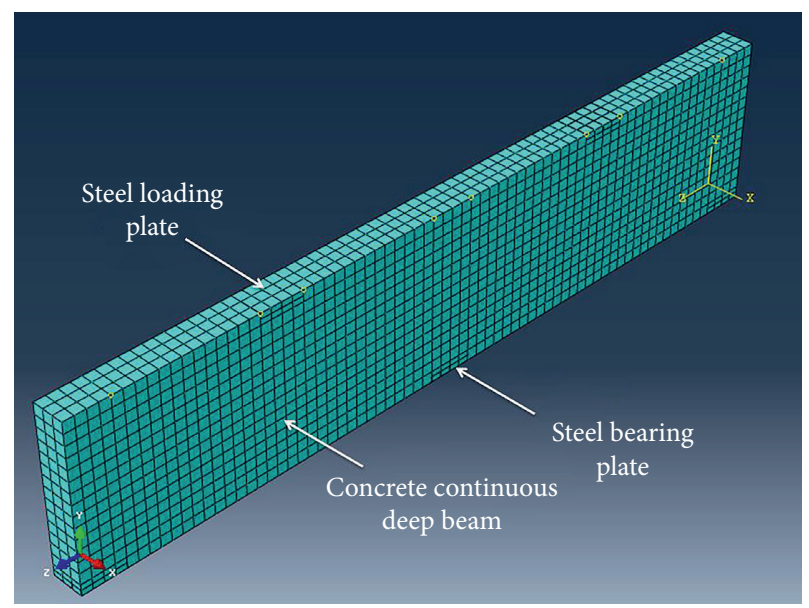

FIGURE 5: FE model and meshing of the continuous deep beam.

properly in similar studies, this model was applied for modeling concrete response [28, 29]. Important parameters to define the CDP model are shown in Table 4 . 
$v_{c}$ is the concrete Poisson's ratio, $\Psi_{c}$ (deg) is the angle of dilation, $f_{b 0} / f_{c 0}$ is equibiaxial to uniaxial compressive stress, and $K$ is the ratio of the second stress invariant on the tensile meridian to that on the compressive meridian at initial yield.

The stress-strain behavior under tension and compression is also needed to describe the CDP model. The concrete stress-strain under compression was modeled based on Hognestad et al. [30]. The model is expressed in equations (1) and (2) as follows and shown in Figure 6.

For $\varepsilon \leq \varepsilon_{0}$,

$$
f_{c}=f_{c}^{\prime}\left[2\left(\frac{\varepsilon}{\varepsilon_{0}}\right)-\left(\frac{\varepsilon}{\varepsilon_{0}}\right)^{2}\right] .
$$

For $\varepsilon_{0} \leq \varepsilon \leq \varepsilon_{u}$,

$$
f_{c}=f_{c}^{\prime}\left[1-0.15\left(\frac{\varepsilon-\varepsilon_{0}}{\varepsilon_{u}-\varepsilon_{0}}\right)\right],
$$

where $f_{c}$ is the concrete compressive stress in MPa, $f_{c}^{\prime}$ is concrete compressive strength in $\mathrm{MPa}, \varepsilon_{0}$ is the strain at peak compressive strength $\left(\varepsilon_{0}=2 f_{c}^{\prime} / E_{c}\right), \varepsilon$ is the compressive strain of concrete, $\varepsilon_{u}$ is the ultimate concrete compressive strain, and $E_{c}$ is the elasticity modulus of concrete.

The concrete stress-strain diagram in tension is assumed to be linear up to peak tensile stress, and after cracking, it has a linear part up to zero stress at a total strain of 0.001 , as shown in Figure 6. The total strain is usually assumed to be ten times the cracking strain; however, calibration of this value in finite element modeling of concrete has been recommended [26].

In Figure $6, \sigma_{t}$ is the tensile stress, $f_{t}$ is the concrete tensile stress, $E_{c}$ is the elasticity modulus of concrete, $\varepsilon_{c r}$ is the strain at peak tensile strength, and $\varepsilon_{t u}$ is the ultimate concrete tensile strain.

Concrete damage plasticity assumes that a variable, $d$, characterizes the degradation of elastic stiffness. This variable is the function of two damage variables, $d_{c}$ and $d_{t}$, which are uniaxial compressive and tensile damage variables as presented in equation (3). These two variables $\left(d_{c}\right.$ and $\left.d_{t}\right)$ are assumed to be functions of their corresponding plastic strains, $\varepsilon_{c}^{p l}$ and $\varepsilon_{t}^{p l}$, as presented in equations (4) and (5) [31]. The damage variables can be from zero to one. Zero value is for undamaged material and one is for the total loss of strength.

$$
(1-d)=\left(1-s_{t} d_{c}\right)\left(1-s_{c} d_{t}\right)
$$

$s_{c}$ and $s_{t}$ are the compressive and tensile stiffness recovery, $\sigma_{t}$ and $\sigma_{c}$ are the tensile and compressive stresses, and $E_{c}$ is the initial elastic modulus [26]. In these equations, $b_{c}$ and $b_{t}$ have a constant value of 0.7 and 0.1 , respectively, suggested by Birtel and Mark [31].

$$
\begin{aligned}
& d_{c}=1-\frac{\sigma_{c} / E_{c}}{\varepsilon_{c}^{p l}\left(\left(1 / b_{c}\right)-1\right)+\left(\sigma_{c} / E_{c}\right)}, \\
& d_{t}=1-\frac{\sigma_{t} / E_{c}}{\varepsilon_{t}^{p l}\left(\left(1 / b_{t}\right)-1\right)+\left(\sigma_{t} / E_{c}\right)} .
\end{aligned}
$$

To model the concrete with three different compressive strengths, the tensile strength and the modulus of elasticity were considered as equations (6) and (7), according to ACI318-14 [3].

$$
\begin{aligned}
& f_{t}^{\prime}=0.33 \sqrt{f_{c}^{\prime}} \mathrm{MPa}, \\
& E_{c}=4700 \sqrt{f_{c}^{\prime}} \mathrm{MPa} .
\end{aligned}
$$

The steel reinforcement behavior was considered elastoplastic. The yield and ultimate strength and elastic modulus of reinforcement were described in Table 2. Furthermore, Poisson's ratio was assumed at 0.3.

\subsection{FE Analyses of Tested Specimens and Comparison with} Experimental Study. The numerical analyses of test specimens BT1, BT2, and BT3 were conducted. The resulting load-deflection diagrams are compared to experimental results, and the outcomes are presented in Figure 7. Based on numerical and experimental studies, the yield and ultimate loads are satisfactorily close to each other. As the loaddisplacement diagrams show, the simulated model graphs are stiffer than the experimental tests' outcomes. This issue may come from the fact that microcracks exist in real concrete; however, FE models do not simulate them, though they reduce the stiffness of the RC models [32]. Furthermore, some ambient factors may have affected the stiffness of the experimental specimen.

The numerical failure modes of specimens BT1, BT2, and BT3 are shown in Figure 8. It should be noted that in this figure, the tensile damage of concrete is illustrated to show the concrete cracking. Comparing diagrams in Figure 8 with experimental crack patterns, shown in Figure 3, indicates that both numerical and experimental studies show the same failure modes.

3.3. Numerical Analysis. In this research, the parametric study of 21 continuous RC deep beam models was conducted. Table 5 displays the overall geometric dimensions and the reinforcement information for all the beam models used.

The parametric study was conducted by varying the shear span-to-overall depth ratio $(a / h)$ and the studied beams' concrete compressive strength. First, the shear spanto-overall depth ratio $(a / h)$ was varied by changing the beams' overall depth $(h)$ to come up with different $a / h$ ratios. Second, the concrete compressive strength $\left(f_{c}^{\prime}\right)$ was considered $40 \mathrm{MPa}, 60 \mathrm{MPa}$, and $80 \mathrm{MPa}$, to compare high strength concrete with medium and normal ones. The beam models beginning with the letter $\mathrm{C}$ have a $4000 \mathrm{~mm}$ clear span, $2000 \mathrm{~mm}$ shear span, and $500 \mathrm{~mm}$ width. These beams' overall depth is assumed to be between 1000 and $2000 \mathrm{~mm}$ for various $a / h$ ratios. The beam models beginning with the letter B have a $3000 \mathrm{~mm}$ clear span, $1500 \mathrm{~mm}$ shear span, and $300 \mathrm{~mm}$ width. The height of these beams is assumed to be between 1500 and $4500 \mathrm{~mm}$ for different $a / h$ ratios. Each beam has been evaluated with 3 different compressive 
TABLE 4: CDP parameters.

\begin{tabular}{lcccccc}
\hline Density $\left(\mathrm{kg} / \mathrm{m}^{3}\right)$ & $v_{c}$ & $\Psi_{c}(\mathrm{deg})$ & Eccentricity & $f_{b 0} / f_{c 0}$ & $K$ & Viscosity parameter \\
\hline 2402 & 0.2 & 40 & 0.1 & 1.16 & 0.6667 & 0.0001 \\
\hline
\end{tabular}

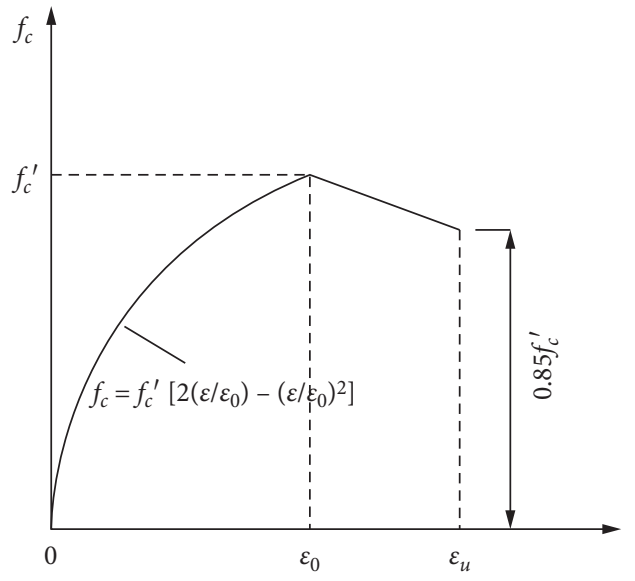

(a)

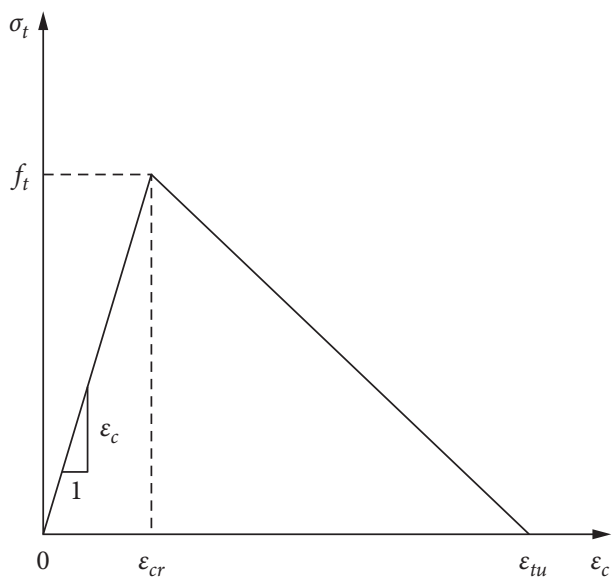

(b)

FIgURE 6: Concrete stress-strain diagram. (a) Under compression. (b) Under tension.
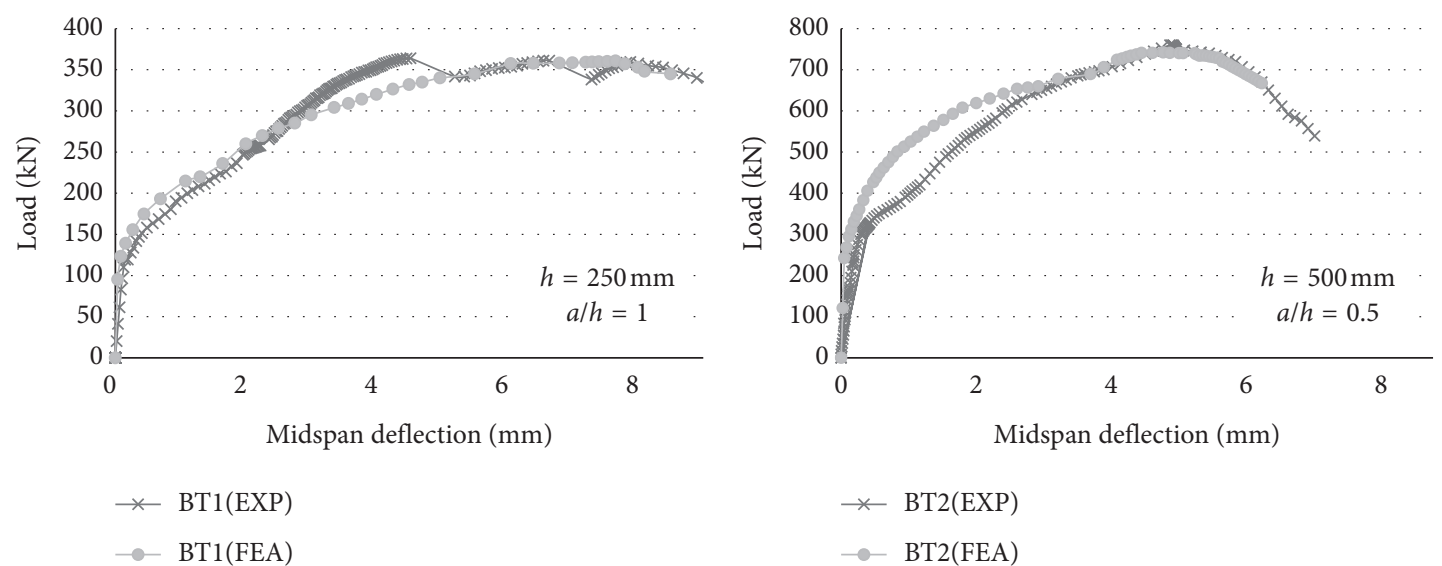

(a)

$*$ BT2(EXP)

$\rightarrow$ BT2(FEA)

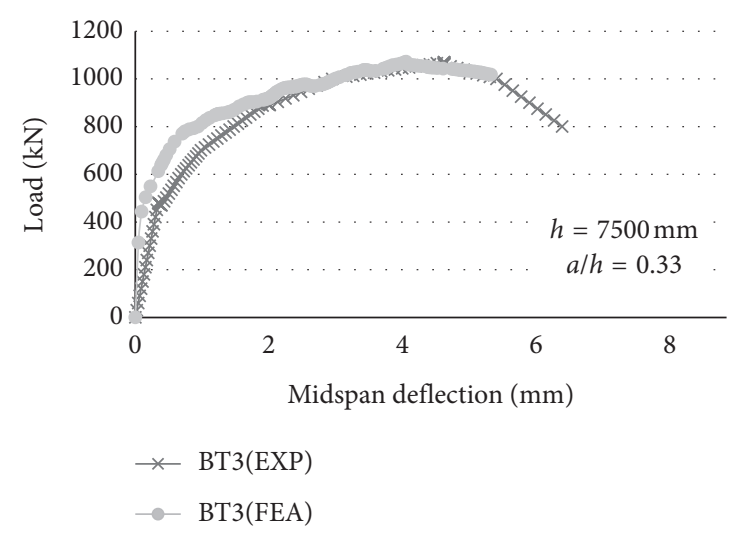

(c)

FIGURE 7: FE versus experimental load-deflection diagrams. (a) BT1. (b) BT2. (c) BT3. 


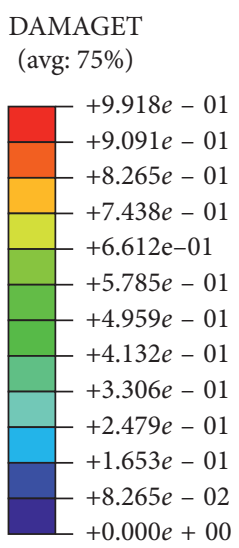

DAMAGET

(avg: 75\%)

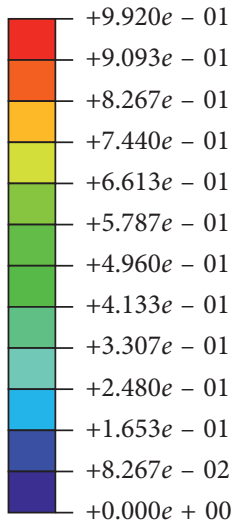

$+0.000 e+00$

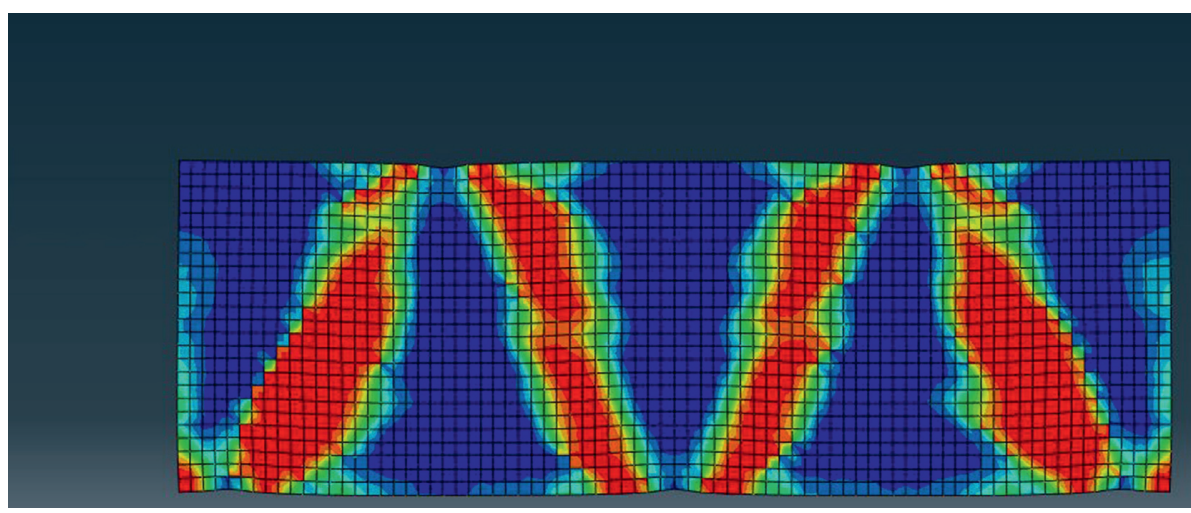

(b)

DAMAGET

(avg: 75\%)
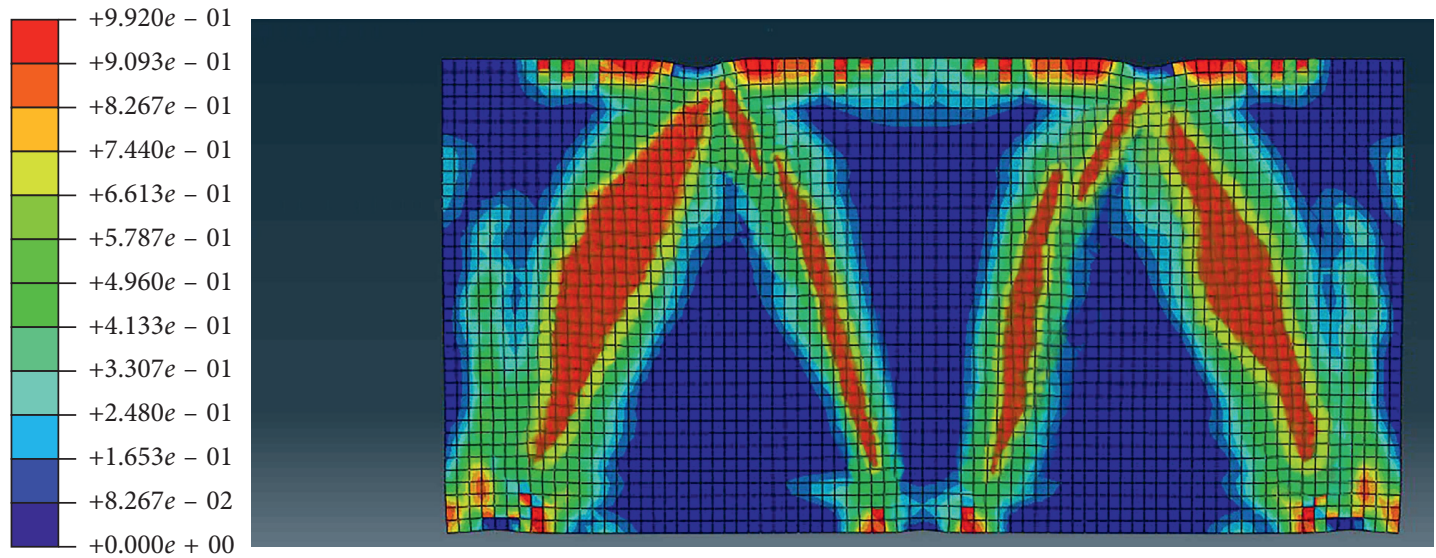

(c)

Figure 8: FE crack patterns at the ultimate state for specimens. (a) BT1. (b) BT2. (c) BT3.

strengths of concrete. The beam models, designated only by $\mathrm{C}$ or $\mathrm{B}$, have a compressive concrete strength of $40 \mathrm{MPa}$. Beam models labeled $\mathrm{CM}$ or $\mathrm{BM}$ have $60 \mathrm{MPa}$ compressive strength, and beams named $\mathrm{CH}$ or $\mathrm{BH}$ have $80 \mathrm{MPa}$ compressive strength. Details of these beam models are shown in Table 5.
3.4. Numerical Analysis Load-Deflection Response. The loaddeflection diagram of continuous deep beams with different $a / h$ ratios and $f_{c}^{\prime}$ is presented in Figure 9. Based on the results, a decrease in $a / h$ ratio causes a rise in the stiffness and ultimate load capacity of the beam models similar to Singh [2] and Yang and Ashour's [19] studies. Beams with 
TABle 5: Beams' geometrical and reinforcement specifications.

\begin{tabular}{|c|c|c|c|c|c|c|c|c|c|}
\hline \multirow[t]{2}{*}{ Beam name } & \multirow{2}{*}{$f_{c}^{\prime}(\mathrm{MPa})$} & \multirow[t]{2}{*}{$a(\mathrm{~mm})$} & \multirow[t]{2}{*}{$h(\mathrm{~mm})$} & \multirow[t]{2}{*}{$d(\mathrm{~mm})$} & \multirow[t]{2}{*}{$a / h$} & \multicolumn{2}{|c|}{$\begin{array}{l}\text { Longitudinal } \\
\text { reinforcement ratio }\end{array}$} & \multicolumn{2}{|c|}{ Web reinforcement ratio } \\
\hline & & & & & & Bottom & Top & Vertical & Horizontal \\
\hline $\mathrm{C} 1$ & 40 & 2000 & 1000 & 900 & 2 & 0.017 & 0.017 & 0.003 & 0.003 \\
\hline CM1 & 60 & 2000 & 1000 & 900 & 2 & 0.022 & 0.022 & 0.039 & 0.039 \\
\hline $\mathrm{CH} 1$ & 80 & 2000 & 1000 & 900 & 2 & 0.026 & 0.026 & 0.0049 & 0.0049 \\
\hline $\mathrm{C} 2$ & 40 & 2000 & 1500 & 1400 & 1.33 & 0.017 & 0.017 & 0.0036 & 0.0036 \\
\hline CM2 & 60 & 2000 & 1500 & 1400 & 1.33 & 0.022 & 0.022 & 0.005 & 0.005 \\
\hline $\mathrm{CH} 2$ & 80 & 2000 & 1500 & 1400 & 1.33 & 0.026 & 0.026 & 0.006 & 0.006 \\
\hline $\mathrm{C} 3$ & 40 & 2000 & 2000 & 1900 & 1 & 0.017 & 0.017 & 0.0036 & 0.0036 \\
\hline CM3 & 60 & 2000 & 2000 & 1900 & 1 & 0.022 & 0.022 & 0.0055 & 0.0055 \\
\hline $\mathrm{CH} 3$ & 80 & 2000 & 2000 & 1900 & 1 & 0.026 & 0.026 & 0.007 & 0.007 \\
\hline B1 & 40 & 1500 & 1500 & 1400 & 1 & 0.0067 & 0.0067 & 0.003 & 0.003 \\
\hline BM1 & 60 & 1500 & 1500 & 1400 & 1 & 0.0086 & 0.0086 & 0.003 & 0.003 \\
\hline $\mathrm{BH} 1$ & 80 & 1500 & 1500 & 1400 & 1 & 0.0086 & 0.0086 & 0.003 & 0.003 \\
\hline B2 & 40 & 1500 & 2000 & 1900 & 0.75 & 0.0065 & 0.0065 & 0.003 & 0.003 \\
\hline BM2 & 60 & 1500 & 2000 & 1900 & 0.75 & 0.0085 & 0.0085 & 0.003 & 0.003 \\
\hline $\mathrm{BH} 2$ & 80 & 1500 & 2000 & 1900 & 0.75 & 0.0085 & 0.0085 & 0.003 & 0.003 \\
\hline B3 & 40 & 1500 & 3000 & 2900 & 0.5 & 0.0074 & 0.0074 & 0.003 & 0.003 \\
\hline BM3 & 60 & 1500 & 3000 & 2900 & 0.5 & 0.0083 & 0.0083 & 0.003 & 0.003 \\
\hline $\mathrm{BH} 3$ & 80 & 1500 & 3000 & 2900 & 0.5 & 0.0083 & 0.0083 & 0.003 & 0.003 \\
\hline B4 & 40 & 1500 & 4500 & 4400 & 0.33 & 0.0069 & 0.0069 & 0.003 & 0.003 \\
\hline BM4 & 60 & 1500 & 4500 & 4400 & 0.33 & 0.0082 & 0.0082 & 0.003 & 0.003 \\
\hline $\mathrm{BH} 4$ & 80 & 1500 & 4500 & 4400 & 0.33 & 0.0082 & 0.0082 & 0.003 & 0.003 \\
\hline
\end{tabular}

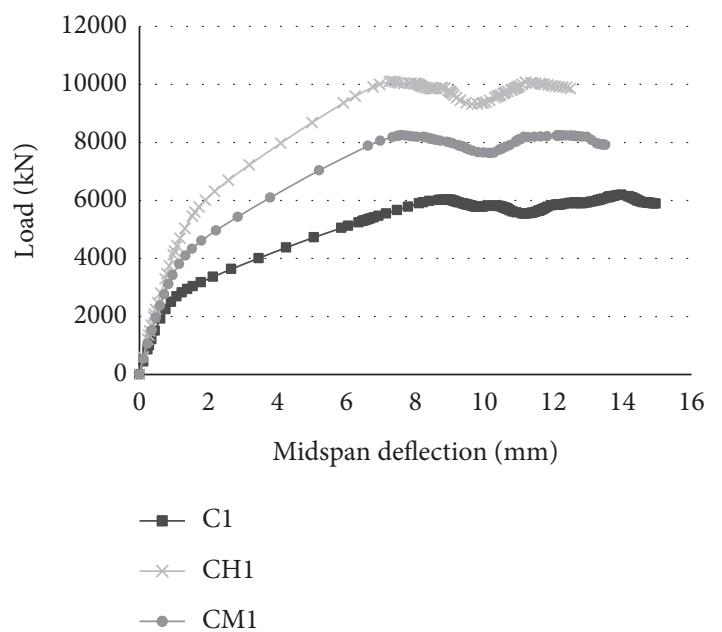

(a)

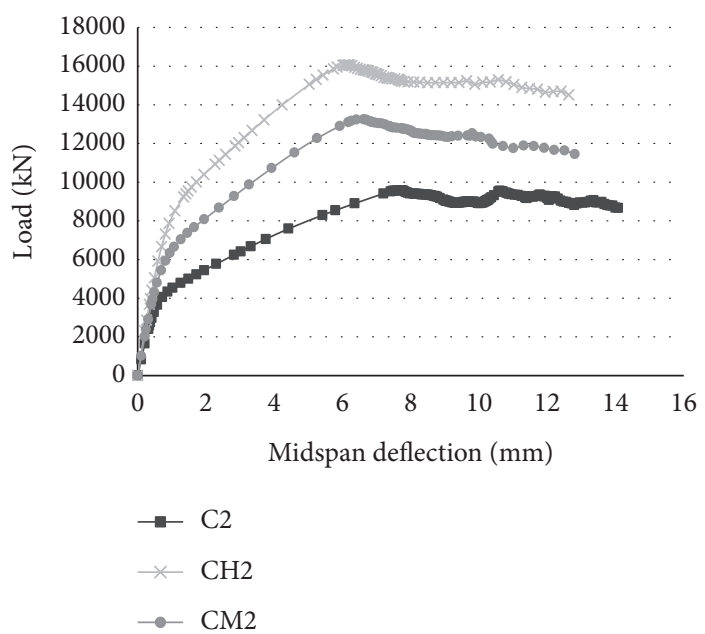

(b)

FIgURe 9: Continued. 


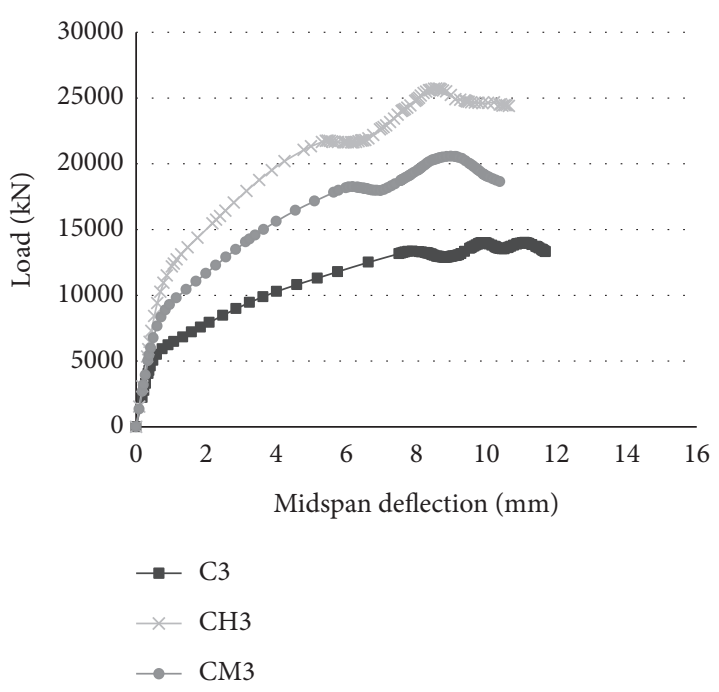

(c)

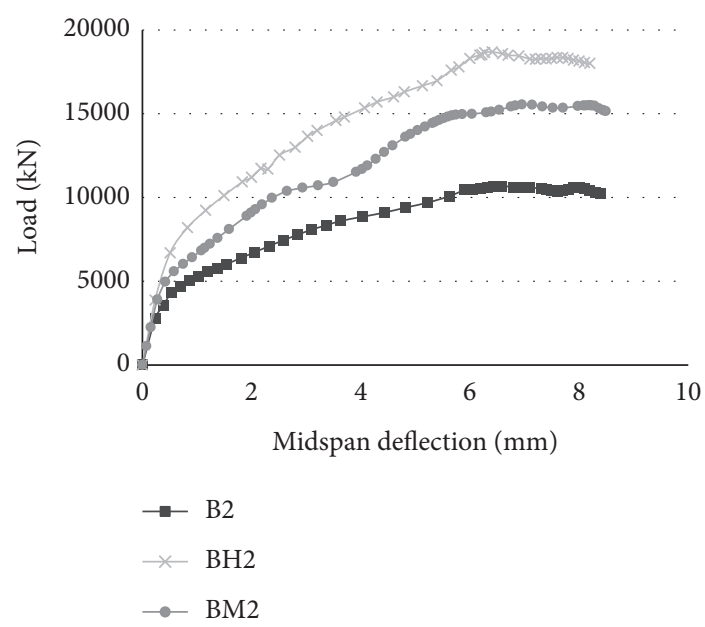

(e)

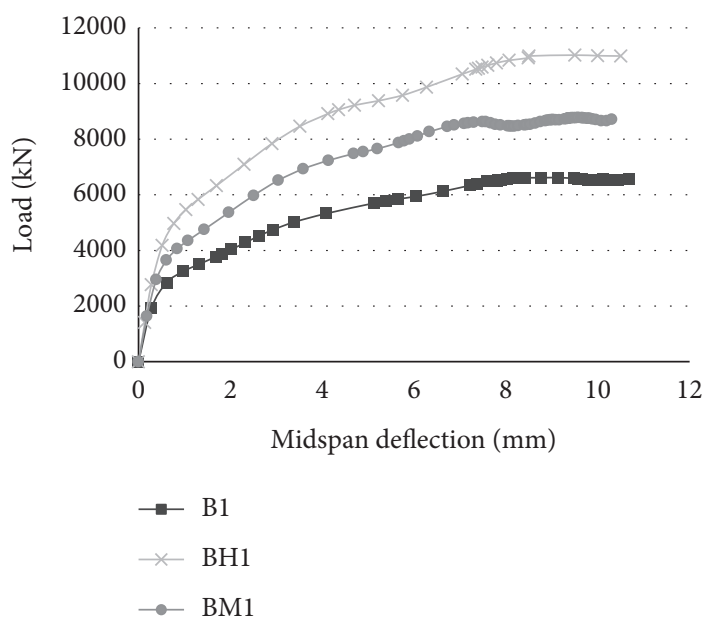

(d)

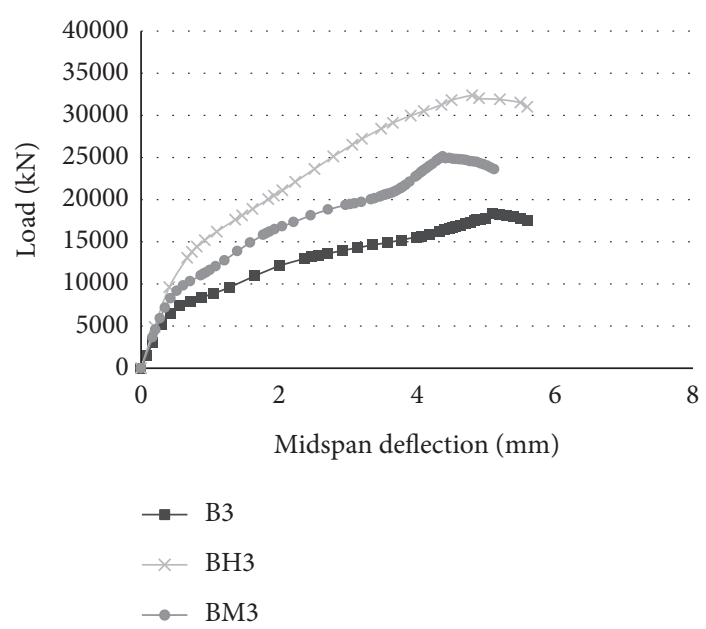

(f)

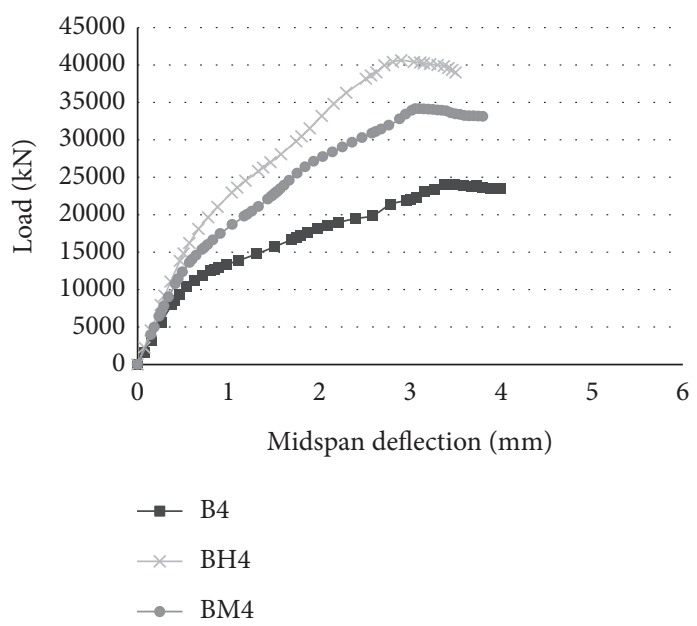

(g)

Figure 9: Load-deflection diagrams of continuous deep beams with different $a / h$ ratios and $f_{c}^{\prime}$. (a) C1, CM1, and CH1. (b) C2, CM2, and $\mathrm{CH} 2$. (c) $\mathrm{C} 3, \mathrm{CM} 3$, and $\mathrm{CH} 3$. (d) B1, BM1, and BH1. (e) B2, BM2, and BH2. (f) B3, BM3, and BH3. (g) B4, BM4, and BH4. 
the same $a / h$ ratio and same overall depth show different initial stiffness as their $f_{c}^{\prime}$ varies from $40 \mathrm{MPa}$ to $80 \mathrm{MPa}$. The deflection of midspan points shows that less deformation and ductility occur when beams have a lower $a / h$ ratio. This can be explained by the fact that beams having large $a / h$ ratios act similarly to the flexural critical structure. Beams with a low $a / h$ ratio are acting similarly to the shear critical structure with an arch load transfer mechanism. As expected, the bearing capacity of beams and initial stiffness increases with adding $f_{c}^{\prime}$ similar to Yang and Ashour's study [19] and confirmed in Figure 9.
3.5. Numerical Results Compared with Design Codes. In ACI 318-14 for analyzing concrete deep beams, the strut-and-tie model (STM) is suggested. Figure 10 shows a graphic STM for continuous reinforced concrete deep beams with twopoint symmetrical top loads $[17,19]$.

The ultimate load-bearing capacity of continuous concrete deep beams $\left(P_{n}\right)$, which shows the failure of struts of concrete, can be obtained from equations (8)-(10):

$$
\begin{aligned}
P_{n} & =\left(v_{e} f_{c}^{\prime} b_{w}\left(w_{t} \cos \theta+\frac{l_{P E}+0.5 l_{p p}}{2} \sin \theta\right)+v_{e} f_{c}^{\prime} b_{w}\left(w_{t} \cos \theta+\frac{l_{P I}+l_{p p}}{4} \sin \theta\right)\right) \sin \theta, \\
\theta & =\tan ^{-1}(B), \\
B & =\frac{\left(h-c-c^{\prime}\right)}{a} .
\end{aligned}
$$

$\theta$ shows the angle between the strut and the longitudinal axis, $a$ is the shear span, $h$ is the overall section depth, $c$ is the cover of bottom reinforcement, $c^{\prime}$ is the cover of top reinforcement, $f_{c}^{\prime}$ is the concrete cylinder compressive strength, $b_{w}$ is the beam width, and $w_{t}=2 c$. As illustrated in Figure $10, l_{p p}, l_{P E}$, and $l_{P I}$ are the widths of loading plates, exterior, and interior support plates.

Each design code utilizes a different effectiveness factor, $v_{e}$, for concrete. Table 6 displays the effectiveness factors indicated in EC2, CSA-A23.3-04, and ACI 318-14.

$v_{e}$ is the effectiveness factor, $\beta_{s}$ is the strut coefficient to account for the effect of cracking and crack-control reinforcement on the effective compressive strength of the concrete, $\alpha_{i}$ is the angle between the reinforcement and a strut, $A_{s i}$ is the total area, $s_{i}$ is bars spacing, $b_{w}$ is the beamwidth, $f_{c}^{\prime}$ is the concrete cylinder compressive strength, $a$ is the shear span, and $d$ is the effective beam depth.

Table 7 indicates a comparison between the numerical analysis result and the design codes STM calculations. The FE analyses show the effect of section depth on shear strength of deep beams, while the strut-and-tie model of ACI, CSA, and BC2 did not take into account this effect. The closest result for the current analysis is the ACI STM. The EC2 ultimate load capacity prediction resulted in conservative values for all continuous deep beams. The final loadbearing prediction of ACI and CSA was conservative for beams with normal and medium strength concrete $\left(f_{c}^{\prime}=40\right.$ and $\left.60 \mathrm{MPa}\right)$. Moreover, ACI's ultimate load predictions underestimate the result of $\mathrm{CH} 2$ and $\mathrm{BH} 1$, and $\mathrm{CSA}$ underestimates the result of $\mathrm{BH} 4$, which are all made of high strength concrete $\left(f_{c}^{\prime}=80 \mathrm{MPa}\right)$. With increasing $f_{c}^{\prime}$ from $40 \mathrm{MPa}$ to $60 \mathrm{MPa}$ and $80 \mathrm{MPa}$, the ACI and CSA final load prediction becomes closer to the same beams' finite element analysis. Also, Table 7 shows that as the $a / h$ ratio decreases, the prediction of CSA becomes closer to the FE analysis. The CSA prediction in beams $\mathrm{C} 1, \mathrm{CM} 1, \mathrm{CH} 1, \mathrm{C} 2, \mathrm{CM} 2$, and $\mathrm{CH} 2$ is too conservative, which may come from the fact that "The Canadian Code" [5] defines deep beam with $1 / h$ ratio less than 2 , and these beams are not considered deep, according to this standard.

In the same shear span-to-depth ratio, with doubling $f_{c}^{\prime}$ from $40 \mathrm{MPa}$ to $80 \mathrm{MPa}$, the failure load of $\mathrm{C} 1, \mathrm{C} 2, \mathrm{C} 3, \mathrm{~B} 1$, $\mathrm{B} 2, \mathrm{~B} 3$, and B4 increases between 1.67 and 1.83 times. An increase of $f_{c}^{\prime}$ from $40 \mathrm{MPa}$ to $60 \mathrm{MPa}$, in the same beams with similar $a / h$ ratios increase the final load of $\mathrm{C} 1, \mathrm{C} 2, \mathrm{C} 3$, $\mathrm{B} 1, \mathrm{~B} 2, \mathrm{~B} 3$, and $\mathrm{B} 4$ between 1.32 and 1.46 times.

\section{Indeterminate Strut-Tie Model for Two-Span Continuous Deep Beams}

In deep beams, a fraction of the load is transferred by the arch function. Considering this load transfer mechanism, ACI318-14 recommends the use of STM [3].

However, the recommended strut-and-tie method only considers the arch function. FIB (2010) has proposed an indeterminate and determinate strut-tie model for deep beams. This model recommended the arch load transfer mechanism for deep beams with $a / z \leq 0.5$ and truss load transfer mechanism for beams with $a / z \geq 2$. It also suggested a combination of truss and arch load transfer mechanism as an indeterminate truss for deep beams with $0.5<a / z<2$ according to Figure 11 [8]. Like FIB's strut-tie model, an indeterminate truss for singlespan deep beams with $1 \leq a / z \leq \sqrt{3}$ has been presented by Foster and Gilbert [35]. Their model suggested the arch function for deep beams with $a / z \leq 1$ and truss load mechanism transfer for deep beams with $a / z \geq \sqrt{3}$. It recommended a combination of truss and arch load transfer mechanism for deep beams with $1 \leq a / z \leq \sqrt{3}$.

Due to the nonlinear behavior in continuous deep beams, the indeterminate external and internal model, which reflects the final load and the complex nonlinear 


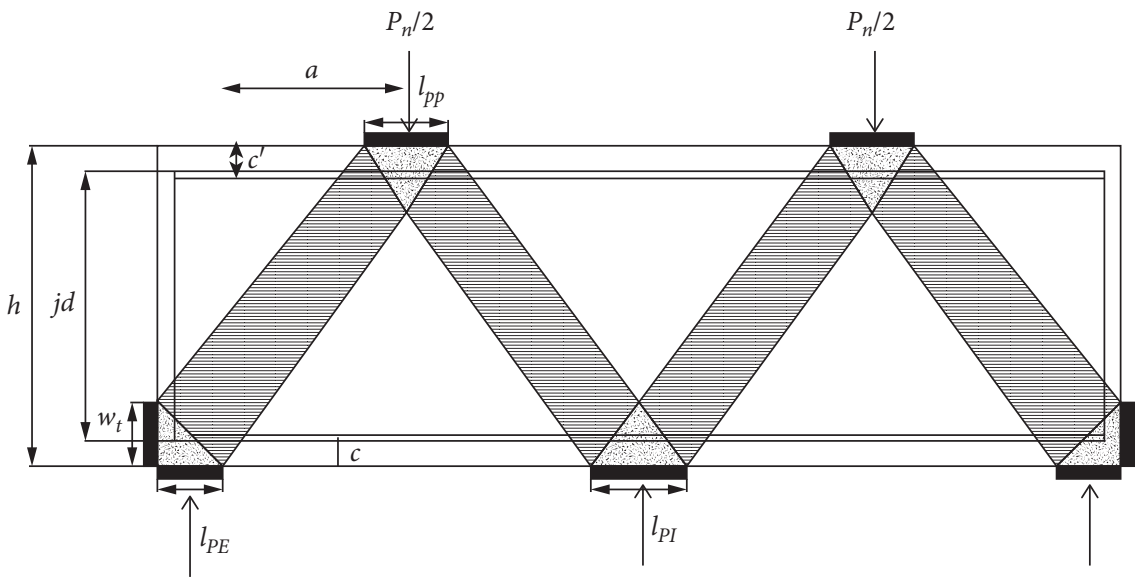

FIgURE 10: Graphic STM for continuous RC deep beams [19, 33].

TABle 6: Different design codes effectiveness factor.

\begin{tabular}{lc}
\hline Design code & Effectiveness factor \\
\hline ACI 318-14 & $v_{e}=0.85 \beta_{s}$ \\
EC2 & if $\sum_{A_{s i} / b_{w} s_{i} \sin \alpha_{i} \geq 0.003 \text {, then } \beta_{s}=0.75 ; \text { otherwise, } \beta_{s}=0.6}$ \\
CSA-A23.3-04 & $v_{e}=0.6\left(1-f_{c}^{\prime} / 250\right)$ \\
$v_{\mathrm{e}}=1 / 1.14+0.68(a / d)^{2}$
\end{tabular}

TABle 7: Comparison of the numerical analysis result and STM of different design codes.

\begin{tabular}{|c|c|c|c|c|c|c|c|c|}
\hline Beam name & $(a / h)$ & FEA (ABAQUS) & ACI 318-14 & CSA & EC2 & FEA/ACI & FEA/CSA & FEA/EC2 \\
\hline $\mathrm{C} 1$ & 2 & 6023 & 5008 & 1457 & 3959 & 1.20 & 4.13 & 1.52 \\
\hline CM1 & 2 & 8244 & 7512 & 2186 & 5373 & 1.09 & 3.77 & 1.53 \\
\hline $\mathrm{CH} 1$ & 2 & 10110 & 10016 & 2915 & 64110 & 1.01 & 3.47 & 1.58 \\
\hline $\mathrm{C} 2$ & 1.33 & 9576 & 8407 & 4553 & 6647 & 1.14 & 2.10 & 1.44 \\
\hline CM2 & 1.33 & 13244 & 12610 & 6829 & 9020 & 1.05 & 1.93 & 1.46 \\
\hline $\mathrm{CH} 2$ & 1.33 & 16061 & 16814 & 9106 & 10761 & 0.96 & 1.76 & 1.49 \\
\hline $\mathrm{C} 3$ & 1 & 14002 & 11195 & 8388 & 8851 & 1.25 & 1.67 & 1.58 \\
\hline CM3 & 1 & 20564 & 16792 & 12581 & 12011 & 1.22 & 1.63 & 1.71 \\
\hline $\mathrm{CH} 3$ & 1 & 25713 & 22390 & 16776 & 14329 & 1.14 & 1.53 & 1.79 \\
\hline B1 & 1 & 6612 & 5775 & 4228 & 5466 & 1.14 & 1.56 & 1.21 \\
\hline BM1 & 1 & 8773 & 8663 & 6342 & 6197 & 1.01 & 1.38 & 1.41 \\
\hline $\mathrm{BH} 1$ & 1 & 11022 & 11551 & 8457 & 7393 & 0.95 & 1.30 & 1.49 \\
\hline B2 & 0.75 & 10683 & 8392 & 7594 & 6635 & 1.27 & 1.41 & 1.61 \\
\hline BM2 & 0.75 & 15551 & 12588 & 11391 & 9004 & 1.23 & 1.36 & 1.72 \\
\hline $\mathrm{BH} 2$ & 0.75 & 18692 & 16785 & 15189 & 10742 & 1.11 & 1.23 & 1.74 \\
\hline B3 & 0.5 & 18326 & 13319 & 14591 & 10530 & 1.38 & 1.26 & 1.74 \\
\hline BM3 & 0.5 & 25104 & 19979 & 21887 & 14291 & 1.25 & 1.14 & 1.75 \\
\hline BH3 & 0.5 & 32345 & 26639 & 29183 & 17049 & 1.21 & 1.11 & 1.90 \\
\hline B4 & 0.33 & 24048 & 17324 & 21281 & 13697 & 1.39 & 1.13 & 1.76 \\
\hline BM4 & 0.33 & 34131 & 25987 & 31921 & 18588 & 1.31 & 1.06 & 1.83 \\
\hline $\mathrm{BH} 4$ & 0.33 & 40623 & 34649 & 42562 & 22176 & 1.17 & 0.95 & 1.83 \\
\hline
\end{tabular}

structural behavior of these beams, is presented in Figure 12 for beams with $a / d \geq 1$ [34]. This indeterminate-type model represents the combination of arch function and truss mechanism [13]. Past studies showed that the role of horizontal shear reinforcement in shear strengthening of beams that do not have too many horizontal reinforcements is not significant. Therefore, in this model, the effect of horizontal shear reinforcement is not considered [24, 25].

In this model, the load distribution ratio, determined as the part of applied load transferred by a vertical tie, was proposed as equations (11) and (12) to help the designing of continuous concrete deep beams [34]. 


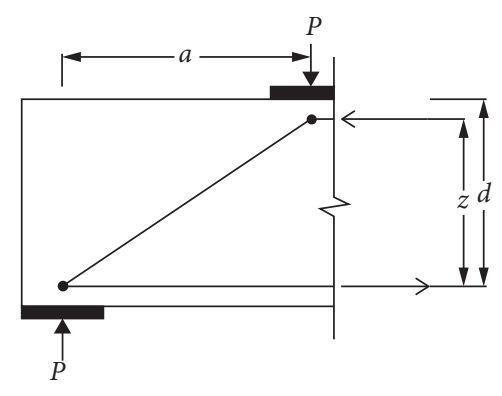

(a)

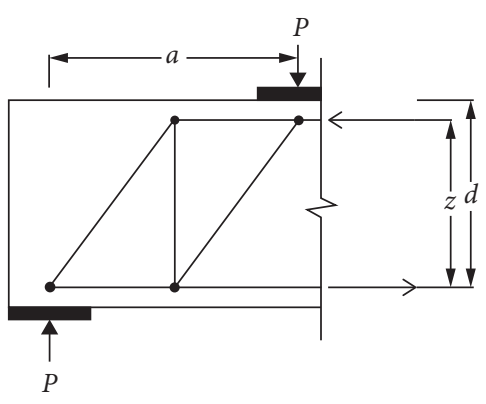

(b)

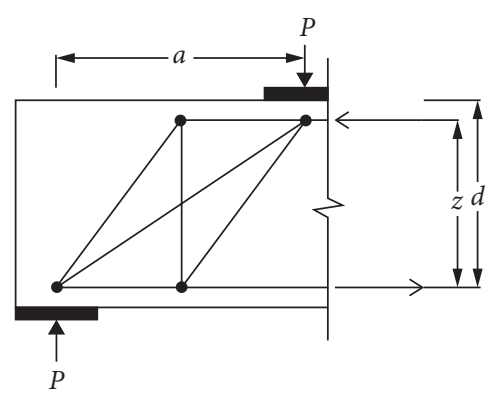

(c)

Figure 11: Strut-tie model for single-span deep beams. (a) Arch mechanism. (b) Truss mechanism. (c) Arch and truss mechanism [34].

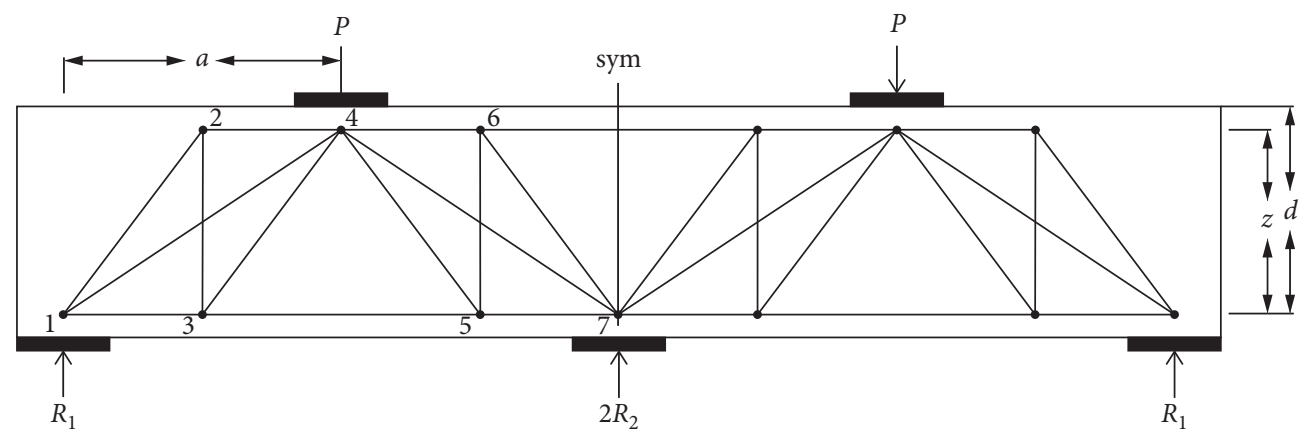

FIGURE 12: Indeterminate truss model for the two-span continuous deep beam [34].

$$
\begin{aligned}
& \alpha=\frac{25}{f_{c}^{\prime}}\left(\frac{a}{d}-\left(1.85-\frac{1}{3}\left(\frac{\rho}{\rho_{b}}\right)\right)\right)+0.6 \text { for } \frac{a}{d}<\left(1.85-\frac{1}{3}\left(\frac{\rho}{\rho_{b}}\right)\right), \\
& \alpha=0.1\left(\frac{a}{d}-\left(1.85-\frac{1}{3}\left(\frac{\rho}{\rho_{b}}\right)\right)\right)+0.6 \text { for } \frac{a}{d} \geq\left(1.85-\frac{1}{3}\left(\frac{\rho}{\rho_{b}}\right)\right) .
\end{aligned}
$$

In these equations, $\alpha$ is the load distribution ratio, $a$ is the shear span, $d$ is the effective depth, $f_{c}^{\prime}$ is the concrete compressive strength, $\rho$ is the flexural reinforcement ratio, and $\rho_{b}$ is the balanced flexural reinforcement ratio.

In the first step, to design a beam with the indeterminate strut-tie method, it is necessary to change the indeterminate truss into a determinate one. The conversion of an indeterminate truss to an externally determinate is done by the load distribution ratio, specified in equation (13) [34].

$$
\gamma=0.011\left(\frac{a}{d}-3\right)^{2}+0.34
$$

where $\gamma$ is the reaction distribution ratio, $a$ is the shear span, and $d$ is the effective depth.

In the second step, the load distribution ratio is used to transfer load with arch and truss functions. As the load increases, one of the arch or truss mechanisms fails. After initial failure, the indeterminate strut-tie model becomes a determinate one that can continue to transfer load by another mechanism. The second load transfer mechanism will fail by increasing the applied load, and the beam loadbearing ends. The important point is that the indeterminate strut-tie method is simultaneously reflecting the truss and arch load transfer mechanisms. The final load-bearing capacity of deep beams with shear failure is based on both mechanisms' consecutive failure.

To show the calculation procedure and effectiveness of the indeterminate STM, beam B1 with $a / h=1$ was selected and analyzed as an indeterminate strut-tie model, shown in Figure 12. The values of $\alpha$ and $\gamma$ for beam B1 were calculated as 0.269 and 0.375 , respectively, according to equations (11)-(13).

The support reactions $(R=\gamma P, P=$ external load applied vertically) and the cross-sectional force of the vertical steel tie $\left(P_{w}=\alpha P\right)$ were calculated. Maximum widths of struts and ties were computed by reaction distribution ratio, load distribution ratio, and nodal zone shapes. Required crosssectional widths (areas) of struts and ties at the first failure were computed. The first failure of beam B1 with the indeterminate strut-tie model was happened by concrete strut as an arch mechanism failure at a load of $4905 \mathrm{kN}$ (74\% of numerical failure load). After initial failure, the indeterminate strut-tie model became determined and capable of transferring the load with struts and truss action ties. The remaining capacity of strut and ties after the first failure was 
TABLE 8: A comparison between the numerical modeling and indeterminate strut-tie model.

\begin{tabular}{|c|c|c|c|c|c|c|c|}
\hline Beam name & $f_{c}^{\prime}(\mathrm{MPa})$ & $(a / h)$ & $\begin{array}{l}\text { Ultimate load } \\
\text { (FEA) }(\mathrm{kN})\end{array}$ & $\begin{array}{c}\text { Ultimate load } \\
\text { (indeterminate strut-tie) }(\mathrm{kN})\end{array}$ & $\begin{array}{l}\text { ACI 318-14 } \\
(\mathrm{kN})\end{array}$ & $\begin{array}{l}\text { FEA/indeterminate } \\
\text { strut-tie }\end{array}$ & FEA/ACI \\
\hline $\mathrm{C} 1$ & 40 & 2 & 6023 & 6018 & 5008 & 1 & 1.20 \\
\hline CM1 & 60 & 2 & 8244 & 7906 & 7512 & 1.04 & 1.09 \\
\hline $\mathrm{CH} 1$ & 80 & 2 & 10110 & 9850 & 10016 & 1.02 & 1.01 \\
\hline $\mathrm{C} 2$ & 40 & 1.33 & 9576 & 9325 & 8407 & 1.02 & 1.14 \\
\hline CM2 & 60 & 1.33 & 13244 & 12649 & 12610 & 1.04 & 1.05 \\
\hline $\mathrm{CH} 2$ & 80 & 1.33 & 16061 & 15886 & 16814 & 1.01 & 0.96 \\
\hline $\mathrm{C} 3$ & 40 & 1 & 14002 & 12970 & 1195 & 1.08 & 1.25 \\
\hline CM3 & 60 & 1 & 20564 & 19455 & 16792 & 1.05 & 1.22 \\
\hline $\mathrm{CH} 3$ & 80 & 1 & 25713 & 23969 & 22390 & 1.07 & 1.14 \\
\hline
\end{tabular}

computed. Adding load, the second failure of the model occurred as a truss action failure. When the second failure happened, the truss became unstable, which could not transfer any more loads. The final load of $6674 \mathrm{kN}$ was estimated with this method. There is a $1 \%$ difference in the estimated final load of FEA and the indeterminate STM method, which is quite acceptable.

To evaluate the performance of numerical studies conducted in this research, beams C1, C2, C3, CM1, CM2, CM3, $\mathrm{CH} 1, \mathrm{CH} 2$, and $\mathrm{CH} 3$ were selected and studied with the indeterminate strut-tie model of Figure 12. The results of the indeterminate strut-tie model, according to Table 8 , have a good agreement with finite element analyses. The difference in the results of FE analyses and indeterminate truss is up to $8 \%$, which is quite acceptable. However, the difference between FEA and ACI318-14 is up to 25\%. In comparing FEA with indeterminate truss, less difference percentage reflects the simultaneous operation of arch and truss function in these beams.

\section{Conclusions}

Based on this study, the FE analyses and experimental tests were conducted. The parameters investigated were $a / h$ ratio and $f_{c}^{\prime}$. The results were compared to the strut-and-tie and indeterminate truss model. The adjacent agreement between the finite element prediction and test results according to load-deflection curves, crack patterns, and ultimate loads indicates the model's reliability. Below are some conclusions obtained based on the research discussed in this paper:

(i) The ultimate strength of concrete beams increased when the $a / h$ ratio decreased, and the midspan deflection decreased with decreasing $a / h$ ratio.

(ii) The place between the support and load plates encountered main diagonal cracks, which caused all tested specimens' failure regardless of the $a / h$ ratio.

(iii) The ultimate strength of continuous deep beams was decisively controlled by concrete compressive strength. Where the concrete compressive strength of two beams with the same $a / h$ ratio increased, the ultimate strength increased remarkably.

(iv) The EC2 ultimate load predictions were conservative for all two-span concrete deep beams. The CSA and ACI final load predictions were unsafe for some of the beam models with high strength concrete. By comparing design codes, the ACI building code put forth the nearest prediction to the analysis compared to the EC2 and the CSA.

(v) The prediction of CSA becomes closer to the FE analysis as the $a / h$ ratio decreased, and with increasing $a / h$ ratio, the FEA/CSA ratio increases

(vi) Comparing the indeterminate truss model with the ACI strut-and-tie model, the indeterminate truss showed closer results with FEA in beams with $a$ / $d \geq 1$, which indicate the concurrent function of arch and truss in these beams.

\section{Notations}

$\begin{array}{ll}L: & \text { Overall length } \\ a: & \text { Shear span } \\ h: & \text { Overall section depth } \\ l: & \text { Clear span } \\ d: & \text { Effective depth of the beam } \\ u_{y}: & \text { Vertical displacement } \\ f_{c}^{\prime}: & \text { Concrete cylinder compressive strength } \\ f_{t}^{\prime}: & \text { Concrete tensile strength } \\ E: & \text { Elasticity modulus } \\ E_{c}: & \text { Concrete initial elastic modulus } \\ d: & \text { Damage variable } \\ d_{c}: & \text { Uniaxial compressive damage variable } \\ d_{t}: & \text { Uniaxial tensile damage variable } \\ \varepsilon_{c}^{p}: & \text { Compressive plastic strain } \\ \varepsilon_{t}^{p l}: & \text { Tensile plastic strain } \\ s_{c}: & \text { Compressive stiffness recovery } \\ s_{t}: & \text { Tensile stiffness recovery } \\ v_{c}: & \text { Concrete Poisson's ratio } \\ \Psi_{c}: & \text { Angle of dilation } \\ f_{b 0} / f_{c 0}: & \text { Ratio of equibiaxial to uniaxial compressive stress } \\ K: & \text { Ratio of the second stress invariant on the tensile } \\ & \text { meridian to that on the compressive meridian at an } \\ f_{c}: & \text { initial yield } \\ \varepsilon_{0}: & \text { Concrete compressive stress } \\ \varepsilon_{u}: & \text { Strain at peak compressive strength } \\ \varepsilon_{u}: & \text { Compressive strain of concrete } \\ \sigma_{c}: & \text { Ultimate concrete compressive strain } \\ f_{t}: & \text { Consile stress } \\ & \text { Conpressive stress } \\ & \end{array}$


$\varepsilon_{c r}: \quad$ Strain at peak tensile strength

$\varepsilon_{t u}: \quad$ Ultimate concrete tensile strain

$\theta$ : Angle between the longitudinal axis and the strut

$c$ : $\quad$ Cover of bottom reinforcement

$c^{\prime}$ : $\quad$ Cover of top reinforcement

$b_{w}=b:$ Beamwidth

$l_{p p}: \quad$ Width of loading plates

$l_{P E}: \quad$ Width of exterior support plates

$l_{P I}: \quad$ Width of interior support plates

$v_{e}: \quad$ Effectiveness factor for concrete

$\alpha_{i}$ : $\quad$ Angle between the reinforcement and a strut

$A_{s i}: \quad$ Total area of reinforcement

$s_{i}: \quad$ Spacing of reinforcement

$\alpha: \quad$ Load distribution ratio

$\rho: \quad$ Flexural reinforcement ratio

$\rho_{b}$ : $\quad$ Balanced flexural reinforcement ratio

$\gamma: \quad$ Reaction distribution ratio

$R: \quad$ Support reaction

$P$ : $\quad$ External load applied vertically

$P_{w}$ : $\quad$ Cross-sectional force of the vertical steel tie.

\section{Data Availability}

The data used to support the findings of this study are available from the corresponding author upon request.

\section{Conflicts of Interest}

The authors declare that they have no conflicts of interest.

\section{References}

[1] A. M. Sayed, X. Wang, and Z. Wu, "Finite element modeling of the shear capacity of RC beams strengthened with FRP sheets by considering different failure modes," Construction and Building Materials, vol. 59, pp. 169-179, 2014.

[2] B. Singh, "Design of a continuous deep beam using the strut and tie method," Asian Journal of Civil Engineering, vol. 7, no. 5, pp. 461-477, 2006.

[3] ACI318, Building Code Requirements for Structural Concrete, ACI, Naples, FL, USA, 2014.

[4] BSI, Design of Concrete Structure-Part 1-1: General Rules and Rules for Buildings, British Standard Institution, London, UK, 2004.

[5] CSA, Design of Concrete Structure, CSA A23.4-04, Canadian Standard Association, Toronto, Canada, 2004.

[6] J. Schlaich, K. Schafer, and M. Jennewein, "Toward a consistent design of structural concrete," PCI Journal, vol. 32, no. 3, pp. 74-150, 1987.

[7] CEN: European Committee for Standardization, Design of Concrete Structure-Part 1-1: General Rules and Rules for Buildings, CEN: European Committee for standardization, Brussels, Belgium, 2004.

[8] FIB, CEP-FIP Model Code 2010, Comite Euro-International du Beton Lausanne, Lausanne, Switzerland, 2010.

[9] G. Aguilar, A. B. Matamoros, G. Parra-Montesinos, and J. K. Wight, "Experimental evaluation of design procedures for shear strength of deep reinforced concrete beams," ACI Structural Journal, vol. 99, no. 4, pp. 539-548, 2002.

[10] A. Arabzadeh, A. R. Rahaie, and R. Aghayari, "A simple strutand-tie model for prediction of ultimate shear strength of RC deep beams," International Journal of Civil Engineering, vol. 7, no. 3, pp. 141-153, 2009.

[11] A. F. Ashour, L. F. Alvarez, and V. V. Toropov, "Empirical modelling of shear strength of RC deep beams by genetic programming," Computers \& Structures, vol. 81, no. 5, pp. 331-338, 2003.

[12] A. H. Gandomi, G. J. Yun, and A. H. Alavi, "An evolutionary approach for modeling of shear strength of RC deep beams," Materials and Structures, vol. 46, no. 12, pp. 2109-2119, 2013.

[13] B.-H. Kim and Y.-M. Yun, “An indeterminate strut-tie model and load distribution ratio for RC deep beams- (II) validity evaluation," Advances in Structural Engineering, vol. 14, no. 6, pp. 1043-1057, 2011.

[14] J. K. Oh and S. W. Shin, "Shear strength of reinforced highstrength concrete deep beams," ACI Structural Journal, vol. 98, no. 2, pp. 164-173, 2001.

[15] F. C. G. Quintero, M. G. J. Parra, and J. K. Wight, "Strength of struts in deep concrete members designed using strut-and-tie method," ACI Structural Journal, vol. 103, no. 4, pp. 577-586, 2006.

[16] H. Chen, W. Yi, Z. J. Ma, and H.-J. Hwang, "Shear strength of reinforced concrete simple and continuous deep beams," ACI Structural Journal, vol. 116, no. 6, pp. 31-40, 2019.

[17] K.-H. Yang, H.-S. Chung, and A. F. Ashour, "Influence of section depth on the structural behaviour of reinforced concrete continuous deep beams," Magazine of Concrete Research, vol. 59, no. 8, pp. 575-586, 2007.

[18] A. F. Ashour and C. T. Morley, "Effectiveness factor of concrete in continuous deep beams," Journal of Structural Engineering, vol. 122, no. 2, pp. 169-178, 1996.

[19] K. H. Yang and A. F. Ashour, "Load capacity of reinforced concrete continuous deep beams," Journal of Structural Engineering, vol. 134, no. 6, pp. 919-929, 2008.

[20] A. Arabzadeh, "Analysis of boundary condition effects on RC deep beams," Structures, vol. 23, pp. 821-830, 2020.

[21] M. A. T. Khatab, A. F. Ashour, T. Sheehan, and D. Lam, "Experimental investigation on continuous reinforced SCC deep beams and Comparisons with Code provisions and models," Engineering Structures, vol. 131, pp. 264-274, 2016.

[22] H. Chen, W. J. Yi, and Z. J. Ma, "Shear-transfer mechanisms and strength modeling of RC continuous deep beams," Journal of Structural Engineering, vol. 146, no. 11, 2020.

[23] L. Librescu and O. Song, Thin-Walled Composite Beams, Springer, Berlin, Germany, 2006.

[24] A. F. Ashour, "Test of reinforced concrete continuous deep beams," ACI Structural Journal, vol. 94, no. 1, pp. 3-11, 1997.

[25] D. M. Rogowsky, J. G. Macgregor, and S. Y. Ong, "Tests of reinforced concrete deep beams," Journal of the American Concrete Institute, vol. 83, no. 4, pp. 614-623, 1986.

[26] Hibbitt Karlsson and Sorensen Inc., Standard Version 6.13-4 and ABAQUS Standard User's Manual, Hibbitt Karlsson and Sorensen Inc., Providence, RI, USA, 2014.

[27] T. Yu, J. G. Teng, Y. L. Wong, and S. L. Dong, "Finite element modeling of confined concrete-I: drucker-Prager type plasticity model," Engineering Structures, vol. 32, no. 3, pp. 665-679, 2010.

[28] R. Malm, "Predicting shear type crack initiation and growth in concrete with non-linear finite element method," Ph.D. thesis, Department of Civil and Architectural Engineering, KTH Royal Institute of Technology, Stockholm, Sweden, 2009.

[29] I. M. Metwally, "Three-dimensional nonlinear finite element analysis of concrete deep beam reinforced with GFRP bars," HBRC Journal, vol. 13, no. 1, pp. 25-38, 2017.

[30] E. Hognestad, N. W. Hanson, and D. McHenry, "Concrete stress distribution in ultimate strength design," ACI Journal Proceedings, vol. 52, no. 12, pp. 455-480, 1995. 
[31] V. Birtel and P. Mark, "Parameterised finite element modelling of RC beam shear failure," in Proceedings of the ABAQUS Users' Conference, Cambridge, MA, USA, May 2006.

[32] A. R. Mohamed, M. S. Shoukry, and J. M. Saeed, "Prediction of the behavior of reinforced concrete deep beams with web openings using the finite element method," Alexandria Engineering Journal, vol. 53, no. 2, pp. 329-339, 2014.

[33] K. H. Yang, H. S. Chung, and A. F. Ashour, "Influence of shear reinforcement on reinforced concrete continuous deep beams," ACI Structural Journal, vol. 104, no. 4, pp. 420-429, 2007.

[34] H. S. Chae and Y. M. Yun, "Strut-tie model for two-span continuous RC deep beams," Computers and Concrete, vol. 16, no. 3, pp. 357-380, 2015.

[35] S. J. Foster and R. I. Gilbert, "Experimental studies on high strength concrete deep beams," ACI Structural Journal, vol. 95, no. 4, pp. 382-390, 1998. 